\title{
Disturbance Legacy on Soil Carbon Stocks and Stability within a Coastal Temperate Forest of Southwestern British Columbia, Canada
}

\author{
Camille E. Defrenne, Julie E. Wilson, Suzanne W. Simard, Les M. Lavkulich \\ Faculty of Forestry, University of British Columbia, Vancouver, Canada \\ Email: c.defrenne@alumni.ubc.ca, julie.wilson@ubc.ca, suzanne.simard@ubc.ca,lml@mail.ubc.ca
}

How to cite this paper: Defrenne, C. E., Wilson, J. E., Simard, S. W., \& Lavkulich, L. M. (2016). Disturbance Legacy on Soil Carbon Stocks and Stability within a Coastal Temperate Forest of Southwestern British Columbia, Canada. Open Journal of Forestry, 6, 305-323.

http://dx.doi.org/10.4236/ojf.2016.65025

Received: April 20, 2016

Accepted: July 30, 2016

Published: August 2, 2016

Copyright (๑) 2016 by authors and Scientific Research Publishing Inc. This work is licensed under the Creative Commons Attribution International License (CC BY 4.0).

http://creativecommons.org/licenses/by/4.0/ (c) (i) Open Access

\begin{abstract}
Although it has been recognized that soils play a critical role in carbon storage and that coastal temperate forests have considerable potential to sequester soil organic carbon (SOC), studies related to SOC stocks and stability are scarce in these ecosystems. Forest disturbances may leave legacies on SOC properties and may further compromise SOC storage capacity of these ecosystems. In the Pacific Spirit Regional Park of southwestern British Columbia, we compared SOC stocks and stability among three second-growth forests that have been affected by disturbances of different magnitudes. We collected data on soil chemical and physical properties to estimate SOC content and assess SOC stability. We found that SOC stocks in the forest characterized by low magnitude disturbance were greater than those of the forest characterized by high magnitude disturbance $\left(8.2 \pm 1.3 \mathrm{~kg} \cdot \mathrm{Cm}^{-2}\right.$ versus $5.3 \pm 0.1$ $\mathrm{kg} \cdot \mathrm{Cm}^{-2}$ to $30 \mathrm{~cm}$ depth). SOC was less stable in the highly disturbed forest and subsequent vegetation changes might have further reduced SOC stability. Our results provide insight into the role of disturbance history in the current SOC storage capacity of coastal temperate rainforests of British Columbia.
\end{abstract}

\section{Keywords}

Soil Carbon, Coastal Forest, Disturbances History, Carbon Storage, Carbon Stocks

\section{Introduction}

Coastal temperate rainforests are among the most productive of the terrestrial ecosystems and are comparatively high in the accumulation and storage of soil organic carbon (SOC) (Keith et al., 2009; Nave et al., 2010). In the Pacific Northwest, it has been reported 
that these ecosystems can store up to $289 \mathrm{Mg} / \mathrm{ha}$, compared to $196 \mathrm{Mg} / \mathrm{ha}$ in tropical rainforests and $130 \mathrm{Mg} / \mathrm{ha}$ in boreal forests (Bhatti et al., 2002; Carpenter et al., 2014). Thus, coastal temperate rainforests are good candidates for mitigation of greenhouse gas emissions (Black et al., 2008; Carpenter et al., 2014). However, their SOC stocks have been and are currently being threatened by disturbances. In this study, the term "disturbance" encompasses anthropogenic (e.g., fire due to slash burning, logging practices, etc.) and natural disturbances.

Ecological legacies, or enduring effects of climate, species composition and disturbance history, are important in determining the rates of contemporary ecosystem processes (Carrillo et al., 2012). Latty et al. (2004) showed that in some forest ecosystems, past disturbances left long-term legacy effects on SOC storage. Thus, information on disturbance history is required to improve our understanding of SOC storage and dynamics in temperate forest ecosystems. In this study, the term "history" refers to the chronological record, nature and magnitude (intensity and severity) of the disturbance events. In coastal temperate rainforests of British Columbia mild temperatures and abundant precipitation lead to long growing seasons, highly productive ecosystems dominated by long-lived conifers (such as western red cedar [Thuja plicata Donn] and western hemlock [Tsuga heterophylla Sarg.]) and slow rates of soil organic matter (SOM) decomposition (Waring \& Franklin, 1979). In addition, large, stand-replacing disturbances are infrequent in these ecosystems, which enable succession to old-growth stages dominated by gap-phase disturbance dynamics. The particular combination of climatic, ecological and pedological factors of these forests is of major advantage in the context of climate change (Black et al., 2008). Although it has been recognized that soils play a critical role in carbon storage (Doetterl et al., 2015) and that coastal temperate forests have considerable potential to sequester SOC (Carpenter et al., 2014), studies related to SOC stocks and stability are scarce in these ecosystems.

According to its residence time in the soil, SOC is commonly assigned to three different functional pools: labile, intermediate and recalcitrant (Lützow et al., 2006). Doetterl et al. (2015) posited that the interaction between climate and geochemical factors controls SOC storage and residence time. Schmidt et al. (2011) suggested that the persistence of SOC in the soil (i.e. stability) is driven by the intrinsic properties of SOC as well as physiochemical and biological parameters. As an example, in coastal temperate rainforests of British Columbia, the clay fraction can account for one third of the SOC (Grand \& Lavkulich, 2012). In addition, Grand and Lavkulich (2012) showed that $\mathrm{Fe}$ and $\mathrm{Al}$ can form organometallic complexes with SOC. Yet, as this mechanism enables SOC stabilization, the translocation of $\mathrm{Al}$ and $\mathrm{Fe}$ in the mineral layers of Podzolic soils (dominant in coastal temperate forests of British Columbia) may enhance SOC storage (Eusterhues et al., 2005).

Forest disturbances commonly cause changes in tree species composition, usually shifting from late to early successional species. These changes can strongly influence the stocks and stability of SOC (Nave et al., 2010; Laganière et al., 2013). As an example, Nave et al. (2010) found that the size of C pools responds differently to harvesting and disturbance, and that losses are significantly smaller in mixed conifer stands than in 
hardwood stands. In the Canadian boreal forest, Laganière et al. (2013) showed that SOC stocks developing under aspen [Populus tremuloides Michx.] stands were more stable than under black spruce [Picea mariana Mill. BSP] or jack pine [Pinus banksiana Lamb.] stands. The authors suggested that SOC stocks in the soil surface of black spruce stands might be more vulnerable to decomposition, even though these stocks are greater than under aspen or jack pine stands. Schleuß et al. (2014) showed that deep soils in mixed species stands had a greater concentration of SOC per unit of fine soil particles than those in monospecific stands. As clay-sized particles have been shown to stabilize SOC (Baldock \& Skjemstad, 2000), this result suggests that mixed temperate forest stands have a greater potential for SOC stabilization than pure stands and that tree species composition may have an impact on SOC storage. Likewise, in coastal temperate rainforests, shifts in forest cover towards early successional tree species may have an important impact on SOC stability and storage through soil-plant feedbacks.

Forests in the Pacific Northwest are theoretically capable of storing more SOC than the amount estimated to be currently stored (Homann et al., 2005). Further, Homann et al. (2005) proposed that lower SOC stocks in Pacific Northwest forests could be explained by a combination of natural and anthropogenic disturbances. The early study of Harmon et al. (1990) in coastal forests of western Oregon and Washington showed that C storage is reduced during timber harvesting and does not approach old-growth storage capacity for at least 200 years. In Canadian inland temperate rainforests, intensive harvesting of old-growth forest has resulted in significant reductions in total forest $\mathrm{C}$ stocks and reductions in forest floor C stocks (Matsuzaki et al., 2013). The early study of Lavkulich and Rowles (1971) in coastal temperate rainforests of British Columbia reported the effect of land use on Podzolic soil properties, focusing on the overall effects of converting mature forest to agricultural uses. Grand and Lavkulich (2012) showed that harvest (clear-cutting) of mature coastal temperate forests of British Columbia resulted in additional SOM inputs to the mineral soil, but these inputs were not stabilized or retained in recovering second-growth forests. The present study builds on this earlier research by comparing SOC stocks and stability among three forest sites that differ in disturbance history and tree species composition. As our study was conducted in a regional park, disturbance has been excluded since the middle of the 20th century. This framework enabled us to focus on disturbance legacies on SOC properties.

\section{Materials and Methods}

\subsection{Study Area}

The study was conducted in Pacific Spirit Regional Park (PSRP) $\left(49^{\circ} 15^{\prime} \mathrm{N}, 123^{\circ} 13^{\prime} \mathrm{W}\right)$ in the western most area of the city of Vancouver, British Columbia (Figure 1). PSRP lies within the Coastal Western Hemlock biogeoclimatic zone (CWH) and experienced a mean annual temperature of $10.5^{\circ} \mathrm{C}$ and mean annual precipitation of $1272 \mathrm{~mm}$ (climate normal 1981-2010) (Wang et al., 2012). The park is on a peninsula characterized by a gently rounded plateau (slope averaging $5 \%$ to $10 \%$ and elevation averaging $100 \mathrm{~m}$ asl.). The soils in PSRP are dominated by podzols, developed from glacio-marine till 


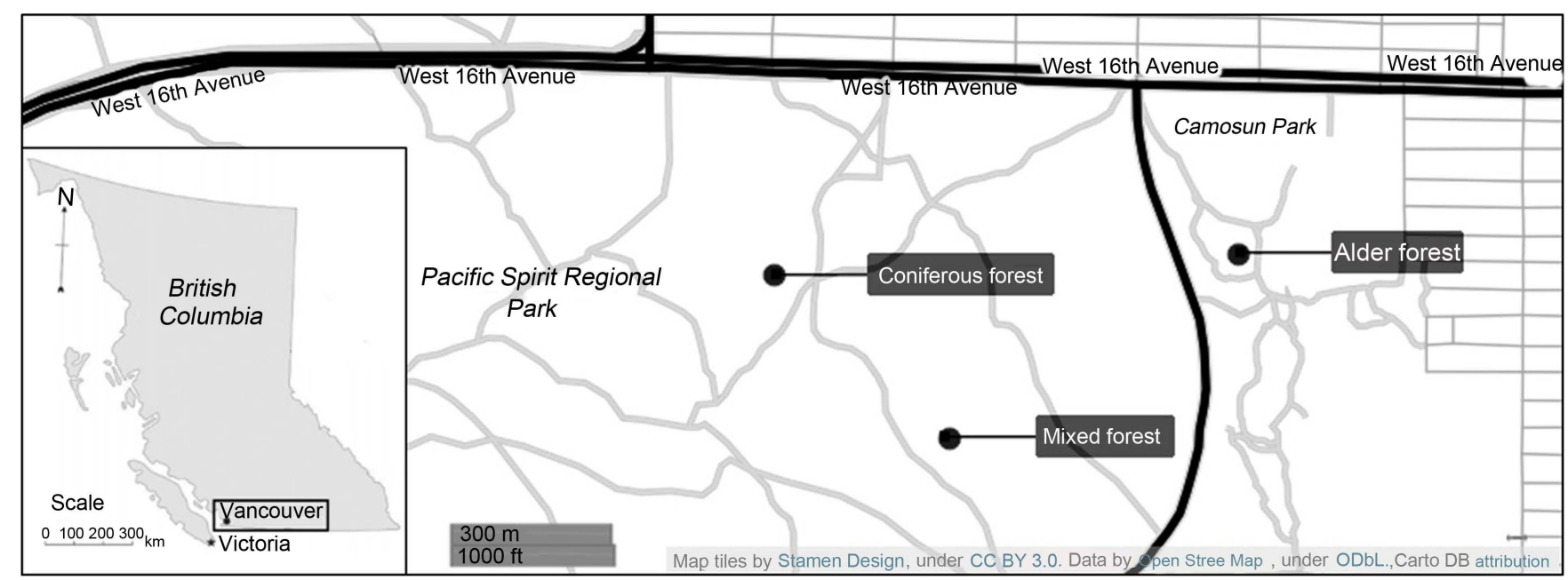

Figure 1. Map showing the location of the three study sites in Pacific Spirit Regional Park (PSRP) within the city of Vancouver. Inset map showing the location the city of Vancouver within the province of British Columbia, Canada.

deposits of sandy to silty texture (Thompson, 1985). PSRP history was well documented in the 1980s, including baseline data on vegetation and soil and records of logging practices (Klassen \& Teversham, 1977; Thompson, 1985). Past disturbance has been the most important factor determining vegetation distribution in PSRP while soil moisture regime has affected plant productivity (Thompson, 1985). According to historical records, PSRP was originally covered by an old-growth forest dominated by Douglas-fir [Pseudotsuga menziesii (Mirb.) Franco], western red cedar and western hemlock (the latter is the climatic climax species in the CWH biogeoclimatic zone) (Klassen \& Teversham, 1977). Trees in the original forest were used by First Nations (mainly western red cedar) before being exploited by European lumber companies (mainly Douglas-fir) in the mid-1800s. These past disturbances (land-clearing, logging or burning) varied in magnitude and have created a mosaic of second-growth forests, including young deciduous forest, mixed coniferous-deciduous forest and pure coniferous forest (Klassen \& Teversham, 1977; Thompson, 1985). Following land clearing, for example, Thompson (1985) reported that the regenerating tree canopy was virtually pure red alder with salmonberry [Rubus spectabilis] in the understory. Following selective logging, by contrast, coniferous trees were retained and these were associated with high levels of red alder and understory conifer regeneration.

To compare SOC stocks and stability among sites that differed in disturbance history, three second-growth forests were selected within PSRP. The characteristics of these sites are provided in Table 1.

The three forest sites were about $500 \mathrm{~m}$ apart and shared the same soil moisture regime (submesic), soil nutrient regime (medium). The soil moisture regime and soil nutrient regime are respectively defined as the average amount of water in the soil annually available for evapotranspiration by plants and the amount of essential nutrient available to plants, in the long-term (Meidinger \& Pojar, 1991).

The three sites had similar site series (CWH dry maritime 01: western hemlock-flat 
Table 1. Characteristics of three forest sites that differ in disturbance history in Pacific Spirit Regional Park, British Columbia, Canada.

\begin{tabular}{|c|c|c|c|c|c|}
\hline Forest site & $\begin{array}{c}\text { Dominant } \\
\text { shrub species }\end{array}$ & $\begin{array}{l}\mathrm{DBH}^{\mathrm{a}}(\text { mean } \pm \mathrm{SEM}) \\
(\mathrm{cm}) / \text { Height } \\
\text { of dominant tree }(\mathrm{m})\end{array}$ & $\begin{array}{l}\text { Successional } \\
\text { status }\end{array}$ & Structural stage & Disturbance history \\
\hline Mixed & $\begin{array}{c}\text { Rubus } \\
\text { spectabilis } \\
\text { Gaultheria } \\
\text { shallon }\end{array}$ & $27 \pm 4 / 50$ & young climax & $\begin{array}{l}\text { understory } \\
\text { reinitiation }\end{array}$ & $\begin{array}{l}\text { Selective logging } \\
\text { + low severity fire }\end{array}$ \\
\hline Coniferous & $\begin{array}{l}\text { Gaultheria } \\
\text { shallon } \\
\text { Vaccinium } \\
\text { parvifolium }\end{array}$ & $46 \pm 3 / 40$ & mature seral & $\begin{array}{l}\text { understory } \\
\text { reinitiation }\end{array}$ & $\begin{array}{l}\text { Selective logging } \\
+ \text { high severity fire }\end{array}$ \\
\hline Alder & Rubus spectabilis & $13 \pm 1 / 23$ & mid seral & $\begin{array}{l}\text { stem exclusion/ } \\
\text { understory } \\
\text { reinitiation }\end{array}$ & $\begin{array}{l}\text { Selective logging + } \\
\text { fire }+ \text { clearing }\end{array}$ \\
\hline
\end{tabular}

Note: ${ }^{a}$ Diameter at breast height: $1.3 \mathrm{~m}$.

moss) and topography (100 m asl., slope between $0 \%$ and $9 \%$ with a northeast aspect, located on a moderately well-drained middle slope) (British Columbia Ministry of Forests and Range, 2010). All forest soils were Orthic Humo-Ferric Podzols based on morphological and chemical analyses, criteria of the Canadian System of Soil Classification, and existing literature on the study area (Lavkulich \& Rowles, 1971; Thompson, 1985; Soil Classification Working Group, 1998). Based on these similarities, the three forest sites differed only in their disturbance history and species composition. Thus, given the identical local site conditions, it was determined that disturbance history played the dominant role in controlling regeneration patterns and soil properties of the three forests. The three second-growth forests were labelled as "mixed", "coniferous" and "alder" depending on the species composition. The "mixed forest" $\left(49^{\circ} 15^{\prime} 06.97 " \mathrm{~N}\right.$; $123^{\circ} 12^{\prime} 30.41^{\prime \prime} \mathrm{W}$ ) was dominated by a mixture of coniferous and deciduous trees, including Douglas-fir, western red cedar and red alder [Alnus rubra]. The "coniferous forest" ( $\left.49^{\circ} 15^{\prime} 18.05^{\prime \prime N} ; 123^{\circ} 12^{\prime} 42.26^{\prime \prime} \mathrm{W}\right)$ was composed of Douglas-fir and western hemlock (dominant tree species). The "alder forest" $\left(49^{\circ} 15^{\prime} 17.28^{\prime \prime N} ; 123^{\circ} 12^{\prime} 00.25^{\prime \prime} \mathrm{W}\right)$ was dominated by red alder (with vine maple and western red cedar as sub-canopy tree species).

\subsection{Disturbance History}

All three forest sites have undergone selective logging and have been affected by fire. In the mid-1800s, selective logging consisted of high grading (mainly Douglas-fir trees) and during the early 1990s, it consisted of removing patches of timber that had not been harvested earlier. The present alder dominated forest has also undergone land-clearing which consisted of removing all the remaining stumps with explosives and clearing the ground of organic layers (Thompson, 1985).

The mixed forest site was selectively logged prior to the early 1900s. In 1919, a brush fire started $300 \mathrm{~m}$ southeast of the site and moved west through logging slash and timber 
(Thompson, 1985). Mature Douglas-fir trees left after selective logging were spared (Klassen \& Teversham, 1977). The fire killed the juvenile Douglas-fir which had been established following selective logging while the western red cedar germinated shortly after fire and red alder established periodically amongst the older Douglas-fir and cedar seedlings (Klassen \& Teversham, 1977; Thompson, 1985).

The coniferous forest was selectively logged around 1900 then burned in 1919 (Thompson, 1985). The current even-aged structure of the forest suggests the fire was severe enough to eliminate the slash, forest floor and seed bank. The mineral soil that was exposed aided the establishment and growth of Douglas-fir (Thompson, 1985).

The alder forest site was selectively logged in the late 1800s. The site was burned by the fire of 1919 and cleared for a housing development (which did not take place) in 1920s. All remaining patches of timber, previously passed over as unsuitable for shipping, and big stumps were cleared. The soil was disturbed to a depth of half a meter in places, and the ground was cleared to mineral soil. The site was cleared again in 1951 for development (which did not take place again) (Thompson, 1985). To summarize, the three second-growth forests are the result of disturbance events of different magnitudes. Within this comparative framework, the mixed forest has experienced disturbance of "low" magnitude, the coniferous forest of "intermediate" magnitude, and the alder forest of "high" magnitude.

\subsection{Soil Sampling}

Soils were sampled in three replicate plots ( $2 \mathrm{~m}$ radius) randomly located along a 100 meter transect in each forest site. Soil series, site series and topography were the same among plots along each transect. A soil pit was located in the middle of each plot along the transect. A circular reference plot (10 m radius) was located in the centre of the transect for describing the ecosystem and identifying plant species according to the British Columbia Ministry of Forests and Range (2010) and to the expertise of a forest ecologist (Pr. S. Simard, personal communication). In April 2014, the soil pits were excavated by hand ( $100 \mathrm{~cm}$ in diameter to the depth of the solum) and sampled by morphological horizon (soil samples were collected from the upper to the lower part of each horizon to represent the entire horizon). Soil horizons were classified according to the Canadian System of Soil Classification (Soil Classification Working Group, 1998). The solum, defined as the layers that have undergone soil forming processes (Soil Classification Working Group, 1998), ranged from about $30 \mathrm{~cm}$ (alder forest) to $60 \mathrm{~cm}$ (mixed and coniferous forests) in depth. The following sequence of horizons was observed in the mixed and coniferous forests: $\mathrm{L}, \mathrm{F}$ and $\mathrm{H}, \mathrm{AB}, \mathrm{Bf}_{1}, \mathrm{Bf}_{2}, \mathrm{BC}, \mathrm{C}$; and in the alder forest: $\mathrm{Ah}, \mathrm{Bf}_{1}, \mathrm{Bf}_{2}, \mathrm{C}$. Forest floors in the mixed and coniferous forests were separated into two components: (1) L and (2) FH. The L layer was thin and patchy, and dominated by coarse woody debris. Only the FH layer was sampled for laboratory analyses. The transitional horizon, $\mathrm{AB}$, was not present in all soil pits of the three forests and when present was thin and discontinuous; as such, it was not taken into account in this study. The first illuvial B horizon was sampled to a depth of $10 \mathrm{~cm}$ as it is the diagnostic horizon for the Podzolic order (Soil Classification Working Group, 1998). 


\subsection{Laboratory Analyses}

Soil samples were dried at room temperature (at least 48 hours), crushed with a wooden rolling pin and sieved through a $2 \mathrm{~mm}$ stainless steel sieve (Bate, 1993). Soil pH was measured potentiometrically with 1:2 ratio of soil to $0.01 \mathrm{M} \mathrm{CaCl}_{2}$ (Hendershot et al., 1993). Soil particle-size analysis was performed following the wet sieving method of Kettler et al. (2001). Earlier studies within PSRP have reported that the soils of the study area do not have appreciable amounts of silt or clay (Lavkulich \& Rowles, 1971; Thompson, 1985). Thus, silt and clay were not separated to ensure there was sufficient soil to measure the SOC concentration associated with this fraction. SOM concentration, which is an indicator of fresh, less decomposed material, was estimated using the loss-on-ignition (LOI) method (modified from Kalra and Maynard, 1991). Soil samples (five gram) were heated to $350^{\circ} \mathrm{C}$ for four hours. To measure SOC and nitrogen (N) concentrations, soil samples were oven-dried $\left(<100^{\circ} \mathrm{C}\right)$, finely ground $(<60 \mu \mathrm{m})$ and analyzed by the Dumas combustion method (Sparks et al., 1996) using an elemental CHNS analyser (Vario MICRO Cube). From SOC and N concentrations, the carbon to nitrogen ratio (C:N) was calculated for each horizon. Treatment of soil samples with sodium hypochlorite $(\mathrm{NaOCl})$ was used to oxidize SOC following the modified method of Zimmerman et al. (2007): One gram of organic soil and five gram of mineral soil were oxidised overnight at room temperature with $50 \mathrm{~mL}$ of $6 \%$ (wt/wt) $\mathrm{NaOCl}$. The residue was filtered and washed with deionised water. This procedure was repeated three times. The $\mathrm{NaOCl}$ oxidizes the labile pool of SOC and thus isolates the recalcitrant pool (Kaiser et al., 2002). SOC concentration after chemical treatment was measured with an elemental CHNS analyzer (Vario MICRO Cube) (Zimmerman et al., 2007). Cation exchange capacity (CEC) was determined by the $\mathrm{BaCl}_{2}$ method of Hendershot and Duquette (1986). Reactive Al forms were extracted with acid ammonium oxalate (McKeague \& Day, 1966). The acid ammonium oxalate solution extracts active non-crystalline $\mathrm{Al}$ oxides in the clay fraction and in the whole soil (i.e., organically bound and amorphous forms) (Dahlgren, 1994). The concentrations of ions ( $\mathrm{Al}^{3+}, \mathrm{Ca}^{2+}$, $\mathrm{Mg}^{2+}$, and $\mathrm{K}^{+}$) and of $\mathrm{Al}$ in the extracts were determined by inductively coupled plasma atomic emission spectroscopy (Varian 725-ES ICP Optical Emission Spectrometer).

Soil bulk density (BD) was estimated by the excavation method of Maynard and Curran (1993). However, the large proportion of coarse fragments and/or roots led to large variations in the field measurements of $\mathrm{BD}$. Thus, values for $\mathrm{BD}$ were also estimated using pedotransfer functions as suggested by Grand and Lavkulich (2011). The pedotransfer functions are based on the correlation between BD and SOC (or SOM) concentration in soil horizons (Heuscher et al., 2005; Périé \& Ouimet, 2008). For BD of mineral soil horizons, we used the empirical regression (Equation (1)) developed by Heuscher et al. (2005) for the Orthod Spodosol great group (Humo-Ferric Podzols).

$$
\mathrm{BD}=1.780-0.379(\mathrm{SOC})^{1 / 2}+0.00123 \text { depth } \quad\left(\mathrm{R}^{2}=0.75\right)
$$

BD is the soil bulk density of the mineral soil horizon $(<2 \mathrm{~mm})$ in $\mathrm{g} \cdot \mathrm{cm}^{-3}$, SOC is the soil organic carbon concentration expressed as mass percentage, and depth is the sampled 
depth in $\mathrm{cm}$. For BD of organic layers, we used the pedotransfer function developed Federer et al. (1993) (Equation (2))

$$
\mathrm{BD}=\left(\mathrm{D}_{\mathrm{bm}} \times \mathrm{D}_{\mathrm{bo}}\right) /\left[\left(\mathrm{SOM} \times \mathrm{D}_{\mathrm{bm}}\right)+(1-\mathrm{SOM}) \times \mathrm{D}_{\mathrm{bo}}\right]
$$

where $\mathrm{BD}$ is the bulk density of organic layers, $\mathrm{D}_{\mathrm{bm}}$ is the empirically determined bulk density of the "pure" mineral fraction, $\mathrm{D}_{\mathrm{bo}}$ is the empirically determined bulk density of the "pure" organic fraction, and SOM is soil organic matter concentration expressed here in $\mathrm{g} \cdot \mathrm{g}^{-1}$. We used the empirically determined $\mathrm{D}_{\mathrm{bm}}=1.77 \pm 0.07$ and $\mathrm{D}_{\mathrm{bo}}=0.11 \pm$ 0.01 by the nonlinear model $\left(\mathrm{r}^{2}=0.81\right)$ of Périé and Ouimet $(2008)$, who have established the relationship between SOM concentration and BD in acidic loamy to sandy loam fine fractions of forest soils in Quebec (Canada).

SOC content of each soil horizon was calculated based on estimated BD values $\left(\mathrm{g} \cdot \mathrm{cm}^{-3}\right.$ ) (Equation (1) for $<2 \mathrm{~mm}$ mineral soil or Equation (2) for organic layer), the relative contribution of fine fraction to total soil mass (FE content in $\mathrm{g}^{-\mathrm{g}^{-1}}$ ), horizon thickness $(\mathrm{cm})$, SOC concentration $\left(\mathrm{g} \cdot \mathrm{kg}^{-1}\right)$ and a unit-conversion factor (100) (Equation (3)).

$$
\operatorname{SOC}\left(\mathrm{kg} \cdot \mathrm{m}^{-2}\right)=(\text { SOC concentration } \times \mathrm{BD} \times \text { horizon thickness } \times \text { Fe content }) / 100
$$

As this study focused on the soil solum, the depth of SOC storage was restricted to the organic layer $(\mathrm{FH})$ and mineral horizons to a depth of $60 \mathrm{~cm}$ for the mixed and coniferous forest and to a depth of $30 \mathrm{~cm}$ for the alder forest. Hence, the SOC content calculation did not take into account the $\mathrm{C}$ horizon (i.e., the parent material).

\subsection{Statistical Analyses}

Statistical analyses were performed using Matlab R2010a (Mathworks Co.). One-way analysis of variance (ANOVA) was used to assess the differences in SOC stocks, stability and related variables among the three forest sites. ANOVA were done among forest sites for each horizon. We used Tukey's HSD as a post hoc test. Results are expressed as mean \pm standard error of the mean (SEM) and $\alpha=0.05$.

\section{Results}

\subsection{Soil Properties and SOC Stocks}

All soils had an acidic $\mathrm{pH}$ (Table 2). The $\mathrm{pH}$ values were similar between the mixed and coniferous forests, ranging from an average of $2.9 \pm 0.1$ in the FH layer to an average of $4.4 \pm 0.1$ in the $\mathrm{Bf}_{2}$ horizon. The alder forest soil horizons were less acidic, by approximately $1 \mathrm{pH}$ unit, ranging from an average of $4.1 \pm 0.1$ in the first horizon to an average of $4.7 \pm 0.1$ in the $\mathrm{Bf}_{2}$ horizon. For the mineral horizons, the percentage of sand $(2 \mathrm{~mm}-50 \mu \mathrm{m})$ was similar in the mixed and coniferous forest (Table 2). In comparison the alder forest soil horizon had almost double the content of silt and clay $(<50$ $\mu \mathrm{m}$ ), averaging $43 \%$ of silt and clay for all horizons. The textural class was loamy sand for the mixed and coniferous forests and sandy loam for the alder forest. Estimated soil $\mathrm{BD}$ values were similar between the mixed and coniferous forests, ranging from an 
Table 2. Sequence of soil horizons and selected soil properties of three forest sites that differ in disturbance history (Mean \pm SEM, $\mathrm{n}=3$ ).

\begin{tabular}{|c|c|c|c|c|c|c|}
\hline \multirow{2}{*}{$\begin{array}{c}\text { Forest site and } \\
\text { soil horizon } \\
(\text { depth, cm) }\end{array}$} & $\mathrm{pH} \mathrm{CaCl}{ }_{2}$ & Sand & Silt \& clay & $\mathrm{BD}^{\mathrm{a}}$ & SOC (silt \& clay) ${ }^{\mathrm{b}}$ & SOC (sand) \\
\hline & $\mathrm{g} \cdot \mathrm{cm}^{-3}$ & \multicolumn{2}{|r|}{$\%$} & $\mathrm{~g} \cdot \mathrm{cm}^{-3}$ & \multicolumn{2}{|l|}{$\%$} \\
\hline \multicolumn{7}{|l|}{ Mixed } \\
\hline $\mathrm{FH}(17-0)$ & $2.9 \pm 0.1$ & - & - & $0.14 \pm 0.02$ & - & - \\
\hline $\mathrm{Bf}_{1}(0-10)$ & $4.2 \pm 0.1$ & $72 \pm 3$ & $28 \pm 3$ & $1.25 \pm 0.07$ & $57 \pm 10$ & $43 \pm 10$ \\
\hline $\mathrm{Bf}_{2}(10-32)$ & $4.4 \pm 0.1$ & $76 \pm 2$ & $24 \pm 2$ & $1.35 \pm 0.01$ & $55 \pm 6$ & $45 \pm 6$ \\
\hline $\mathrm{BC}(32-51)$ & $4.4 \pm 0.1$ & $77 \pm 1$ & $23 \pm 1$ & $1.41 \pm 0.01$ & $63 \pm 5$ & $37 \pm 5$ \\
\hline \multicolumn{7}{|l|}{ Coniferous } \\
\hline $\mathrm{FH}(10-0)$ & $2.9 \pm 0.1$ & - & - & $0.20 \pm 0.04$ & - & - \\
\hline $\mathrm{Bf}_{1}(0-10)$ & $3.6 \pm 0.1$ & $70 \pm 1$ & $30 \pm 1$ & $1.14 \pm 0.02$ & $58 \pm 5$ & $42 \pm 5$ \\
\hline $\mathrm{Bf}_{2}(10-24)$ & $4.4 \pm 0.1$ & $79 \pm 3$ & $21 \pm 3$ & $1.36 \pm 0.07$ & $55 \pm 5$ & $46 \pm 5$ \\
\hline BC $(24-56)$ & $4.7 \pm 0.1$ & $87 \pm 2$ & $13 \pm 2$ & $1.49 \pm 0.02$ & $45 \pm 5$ & $55 \pm 5$ \\
\hline \multicolumn{7}{|l|}{ Alder } \\
\hline $\operatorname{Ah}(0-12)$ & $4.1 \pm 0.1$ & $53 \pm 6$ & $47 \pm 6$ & $1.10 \pm 0.02$ & $55 \pm 3$ & $45 \pm 3$ \\
\hline $\mathrm{Bf}_{1}(12-22)$ & $4.5 \pm 0.1$ & $57 \pm 5$ & $43 \pm 5$ & $1.42 \pm 0.04$ & $73 \pm 3$ & $27 \pm 3$ \\
\hline $\mathrm{Bf}_{2}(22-35)$ & $4.7 \pm 0.1$ & $58 \pm 6$ & $41 \pm 6$ & $1.55 \pm 0.05$ & $70 \pm 9$ & $30 \pm 9$ \\
\hline
\end{tabular}

Note: aSoil bulk density estimated by using pedotransfer functions; ${ }^{b}$ Soil organic carbon concentration measured in the silt \& clay or sand fraction with an elemental analyser.

average of $0.14 \pm 0.02 \mathrm{~g} \cdot \mathrm{cm}^{-3}$ to $1.41 \pm 0.01 \mathrm{~g} \cdot \mathrm{cm}^{-3}$ in the mixed forest and from an average of $0.20 \pm 0.04 \mathrm{~g} \cdot \mathrm{cm}^{-3}$ to $1.49 \pm 0.02 \mathrm{~g} \cdot \mathrm{cm}^{-3}$ in the coniferous forest (Table 2). BD values were slightly higher for the alder forest ranging from an average of $1.10 \pm 0.02$ $\mathrm{g} \cdot \mathrm{cm}^{-3}$ in the Ah horizon to $1.55 \pm 0.05 \mathrm{~g} \cdot \mathrm{cm}^{-3}$ in the $\mathrm{Bf}_{2}$ horizon.

In the mineral horizons of the mixed forest, the average SOM concentration ranged from $35 \pm 8 \mathrm{~g} \cdot \mathrm{kg}^{-1}(\mathrm{BC})$ to $56 \pm 6 \mathrm{~g} \cdot \mathrm{kg}^{-1}\left(\mathrm{Bf}_{1}\right)$ (Figure 2(a)). In the coniferous forest, the average SOM concentration ranged from $24 \pm 4 \mathrm{~g} \cdot \mathrm{kg}^{-1}(\mathrm{BC})$ to $44 \pm 5 \mathrm{~g} \cdot \mathrm{kg}^{-1}\left(\mathrm{Bf}_{1}\right)$ and for the alder forest, from $12 \pm 4 \mathrm{~g} \cdot \mathrm{kg}^{-1}\left(\mathrm{Bf}_{2}\right)$ to $25 \pm 4 \mathrm{~g} \cdot \mathrm{kg}^{-1}\left(\mathrm{Bf}_{1}\right)$. SOM concentration in the $\mathrm{Bf}_{1}$ and $\mathrm{Bf}_{2}$ horizons of the mixed forest was significantly higher than the concentration of that in the alder forest (respectively, $p=0.01$ and $p=0.01$ ). SOM concentration was significantly higher in the $\mathrm{Bf}_{2}$ horizons of the mixed and coniferous forests compared to the alder forest (respectively, $p=0.01$ and $p=0.02$ ). The range in SOC concentration for the mixed forest averaged $13 \pm 1 \mathrm{~g} \cdot \mathrm{kg}^{-1}$ (BC) to $21 \pm 6 \mathrm{~g} \cdot \mathrm{kg}^{-1}\left(\mathrm{Bf}_{1}\right)$. For the coniferous forest, it was on average $8 \pm 1 \mathrm{~g} \cdot \mathrm{kg}^{-1}(\mathrm{BC})$ to $30 \pm 2 \mathrm{~g} \cdot \mathrm{kg}^{-1}\left(\mathrm{Bf}_{1}\right)$ and for the alder forest on average $5 \pm 2 \mathrm{~g} \cdot \mathrm{kg}^{-1}\left(\mathrm{Bf}_{2}\right)$ to $10 \pm 2 \mathrm{~g} \cdot \mathrm{kg}^{-1}\left(\mathrm{Bf}_{1}\right)$ (Figure 2(b)). For the $\mathrm{Bf}_{1}$ horizon, the SOC concentration was significantly higher (six-fold) in the coniferous forest than in the alder forest $(p=0.03)$. The concentration of SOC in the BC horizon was significantly higher in the mixed forest compared with the coniferous forest $(p=0.01)$. 


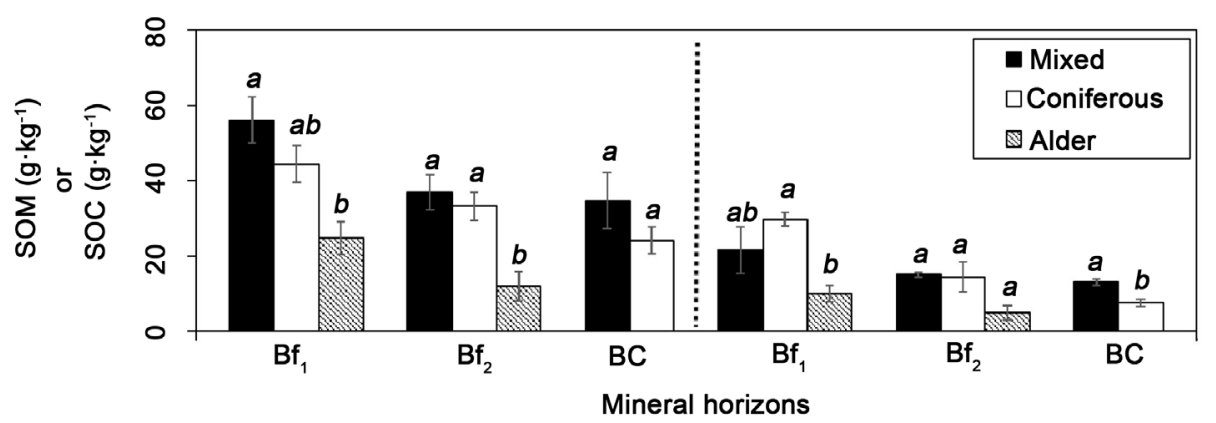

(a)

(b)

Figure 2. Average total soil organic matter (SOM) concentration (a) and average total soil organic carbon (SOC) concentration (b) in mineral horizons of the soil of three second-growth forests that differ in disturbance history. Bars are mean values ( \pm standard error of the mean, $\mathrm{n}=$ 3). Different lowercase letters indicate significant differences by Tukey's HSD test among sites ( $\alpha$ $=0.05)$.

The average SOC content to a depth of $30 \mathrm{~cm}$ was compared among the forest sites (Figure 3(a)). This depth was chosen for comparison among forests as the solum was thicker under the mixed and coniferous forests $(\mathrm{ca} .60 \mathrm{~cm}$ ) than under the alder forest (ca. $30 \mathrm{~cm}$ ). To a depth of $30 \mathrm{~cm}$, the soil of the mixed forest contained on average $8.2 \pm$ $1.2 \mathrm{~kg} \cdot \mathrm{Cm}^{-2}\left(82 \pm 12 \mathrm{MgC} \cdot \mathrm{ha}^{-1}\right)$, compared to on average $3.9 \pm 0.8 \mathrm{~kg} \cdot \mathrm{Cm}^{-2}(39 \pm 8$ $\left.\mathrm{MgC} \cdot \mathrm{ha}^{-1}\right)$ for the soil of the coniferous forest and $5.3 \pm 0.1 \mathrm{~kg} \cdot \mathrm{Cm}^{-2}\left(53 \pm 1 \mathrm{MgC} \cdot \mathrm{ha}^{-1}\right)$ for the soil of the alder forest. The average SOC content to a depth of $30 \mathrm{~cm}$ in the mixed forest was significantly higher than in the coniferous $(p=0.05)$. However, the difference between the mixed and the alder forest was not statistically significant $(p=$ $0.10)$.

The SOC content in the solum of the three forests was also compared (Figure 3(b)). The average SOC content in the solum of the mixed forest was $11.0 \pm 1.5 \mathrm{~kg} \cdot \mathrm{Cm}^{-2}(111$ $\left.\pm 15 \mathrm{MgC} \cdot \mathrm{ha}^{-1}\right)$, and $4.8 \pm 0.8 \mathrm{~kg} \cdot \mathrm{Cm}^{-2}\left(48 \pm 8 \mathrm{MgC} \cdot \mathrm{ha}^{-1}\right)$ for the coniferous forest. This contrasted with $5.3 \pm 0.1 \mathrm{~kg} \cdot \mathrm{Cm}^{-2}\left(53 \pm 1 \mathrm{MgC} \cdot \mathrm{ha}^{-1}\right)$ for the alder forest to a $30 \mathrm{~cm}$ depth. For the mixed forest, the relative contribution of the organic layer to the SOC content of the solum was $61 \%$ versus $52 \%$ for the coniferous forest and $72 \%$ for the surface Ah horizon of the alder forest. Thus, SOC stocks of the mineral horizons accounted for approximately one-third of the total SOC stocks in the mixed and alder forests and half in the coniferous forest.

\subsection{C:N Ratio, Stable SOC and Extractable Al}

For the solum, about $66 \%$ of the total SOC was associated with silt and clay in the alder forest, $58 \%$ in the mixed forest and $53 \%$ in coniferous forest (Table 2). The C:N ratio of the $\mathrm{Bf}_{1}$ horizon was significantly wider in the coniferous forest, reaching an average of $34: 1 \pm 2: 1$ than in mixed and alder forests (respectively, $p=0.005$ and $p=0.0002$ ) (Figure 4). The alder forest had the narrowest $\mathrm{C}: \mathrm{N}$ ratio, averaging 15:1 for the $\mathrm{Bf}_{1}$ and $\mathrm{Bf}_{2}$ horizon (although, the result was not statistically significant between the mixed and alder forest for the $\mathrm{Bf}_{2}$ horizon). 


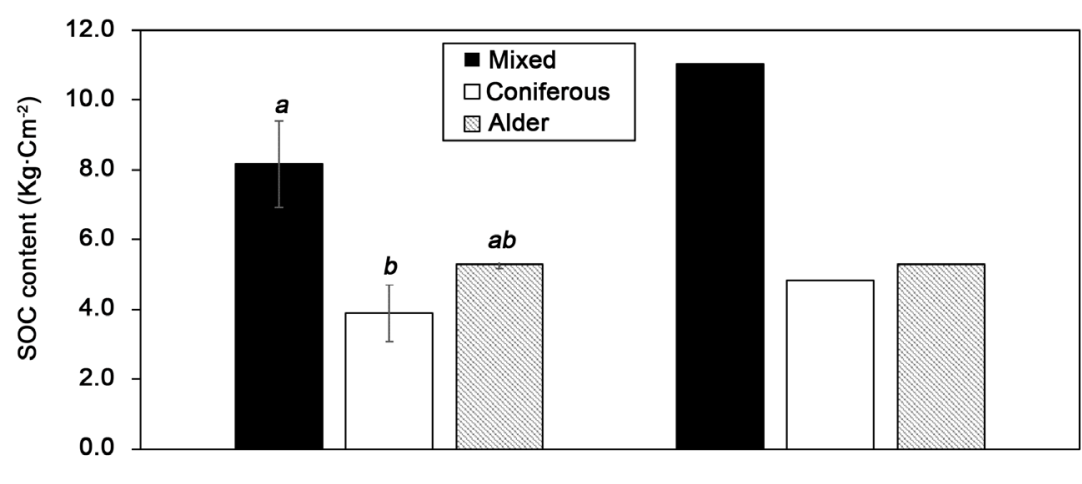

(a)

(b)

Figure 3. Average soil organic carbon (SOC) content to a depth of $30 \mathrm{~cm}$ (a) and to the depth of the solum (b) $(60 \mathrm{~cm}$ for mixed and coniferous and $30 \mathrm{~cm}$ for alder) for three second-growth forests that differ in disturbance history. Bars are mean values ( \pm standard error of the mean, $\mathrm{n}=$ 3). Different lowercase letters indicate significant differences by Tukey's HSD test among sites ( $\alpha$ $=0.05)$. Estimates of error are not given for $(b)$ as the three sites were sampled to different depths, to reflect the thickness of the solum.

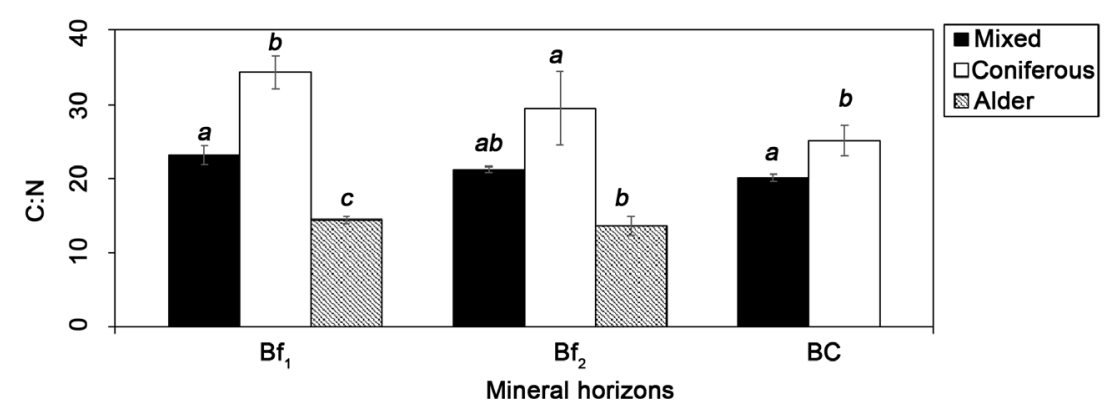

Figure 4. Average carbon to nitrogen ratio (C:N) in the mineral horizons of the soil of three second-growth forests that differ in disturbance history. Bars are mean values ( \pm standard error of the mean, $\mathrm{n}=3$ ). Different lowercase letters indicate significant differences by Tukey's HSD test among sites $(\alpha=0.05)$.

Figure 5 shows the stable SOC concentration in the mineral horizons of the three forests sites. The stable pool of SOC was estimated by the pool of SOC that was not oxidized by $\mathrm{NaOCl}$ (residual SOC). The $\mathrm{Bf}_{1}$ horizon of both the mixed and coniferous forests contained a significantly higher proportion of stable SOC than the Bf1 horizon of the alder forest (respectively, $p=0.02$ and $p=0.04$ ). The $\mathrm{Bf}_{2}$ horizon of the mixed forest had a proportion of stable SOC three times higher than that of the $\mathrm{Bf}_{2}$ horizon of the alder forest $(p=0.05)$.

Results for oxalate-extractable $\mathrm{Al}$ (Table 3 ) show that the mixed forest soil has higher $\mathrm{Al}$ concentrations (in $\mathrm{Bf}_{1}$ and $\mathrm{Bf}_{2}$ horizons) than the alder forest soil although they are not statistically significant ( $p=0.07$ and $p=0.1$ respectively).

\section{Discussion}

This study investigated SOC stocks and stability among three second-growth forests that have resulted from disturbance events of different magnitudes at the beginning of 


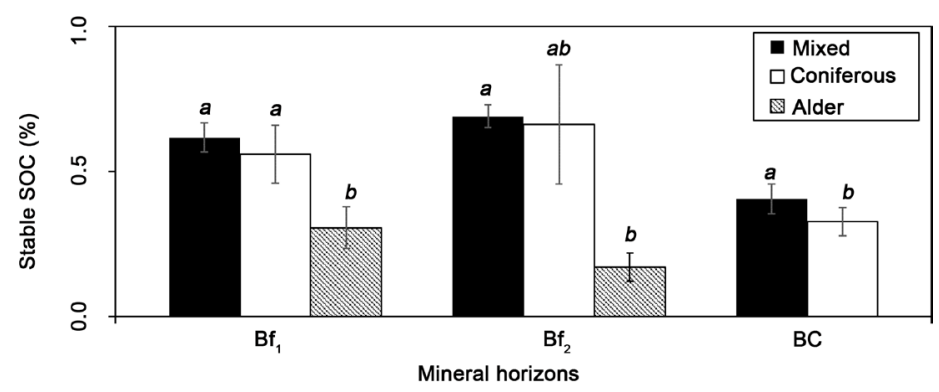

Figure 5. Average total stable soil organic carbon (SOC) concentration (i.e., SOC not oxidized by $\mathrm{NaOCl}$ ) in the mineral horizons of the soil of three second-growth forests that differ in disturbance history. Bars are mean values ( \pm standard error of the mean, $n=3$ ). Different lowercase letters indicate significant differences by Tukey's HSD test among sites $(\alpha=0.05)$.

Table 3. Concentration of oxalate-extractable $\mathrm{Al}$ in the soil of three forest sites that differ in disturbance history (Mean \pm SEM, $\mathrm{n}=3$ ).

\begin{tabular}{cccc}
\hline & \multicolumn{2}{c}{ Oxalate-extractable $\mathrm{Al}\left(\mathrm{g} \cdot \mathrm{kg}^{-1}\right)$} & \\
\hline Soil horizon & Mixed & Coniferous & Alder \\
\hline $\mathrm{FH}$ & $1.3 \pm 0.4$ & $1.2 \pm 0.1$ & N/A \\
$\mathrm{Bf}_{1}$ & $8.7 \pm 1.7$ & $4.0 \pm 1.0$ & $3.9 \pm 0.9$ \\
$\mathrm{Bf}_{2}$ & $8.0 \pm 2.3$ & $8.0 \pm 0.1$ & $2.8 \pm 0.8$ \\
$\mathrm{BC}$ & $6.8 \pm 1.3$ & $9.5 \pm 0.3$ & N/A \\
\hline
\end{tabular}

Note: N/A: not available. The soil of the alder forest does not have a FH layer and BC horizon.

the $20^{\text {th }}$ century. Apart from disturbance history (that played a major role in the vegetation regeneration patterns) all covariate factors were kept constant. Although, we acknowledge our small sample size, this original framework enabled us to focus on disturbance legacies on SOC properties in coastal temperate forest ecosystems. We found that the mixed forest store more $\mathrm{SOC}$ to $30 \mathrm{~cm}$ depth that the coniferous and alder forests, although the results were not statistically significant and that stable SOC concentration is lowest in the alder forest, in combination with a narrow C:N ratio and a low extractable $\mathrm{Al}$ concentration.

\subsection{Disturbance Legacies on SOC Stocks}

The SOC content of the mixed forest in our study was similar to that of undisturbed Douglas-fir plantations in the Pacific Northwest that had established on glacial till and medium soil nutrient regime ( $7.1 \mathrm{~kg} \cdot \mathrm{Cm}^{-2}$ to $20.1 \mathrm{~kg} \cdot \mathrm{Cm}^{-2}$ to $1 \mathrm{~m}$ depth) (Carpenter et al., 2014). The SOC content (30 cm depth) in the mixed forest was higher than in the coniferous and alder forest. The SOC content of the solum was also higher in the mixed forest compared to the coniferous and alder forest and generally, the coniferous and alder forests had similar SOC stocks. This result suggests that the relatively low magnitude disturbances that characterized the mixed forest led to a lower decrease in SOC stocks than in the more severely disturbed alder forest. However, differences in SOC stocks between the moderately disturbed site (coniferous forest) and the highly disturbed site (alder forest) were small (e.g. $4.8 \mathrm{~kg} \cdot \mathrm{Cm}^{-2}$ stored to $60 \mathrm{~cm}$ depth in the coniferous forest compared to $5.3 \mathrm{~kg} \cdot \mathrm{Cm}^{-2}$ stored to $30 \mathrm{~cm}$ depth in the alder forest). Un- 
fortunately, it was not possible to compare our results with the original old-growth forest present in PSRP before the European settlement. However, it was possible to compare our results with an old-growth forest studied in the vicinity of our study area $\left(49^{\circ} 27^{\prime} \mathrm{N}, 123^{\circ} 41^{\prime} \mathrm{W}\right.$; on the Sunshine Coast of southwestern BC) by Grand and Lavkulich (2011). These authors assessed the SOC content in an average profile to a $100-\mathrm{cm}$ depth in a140 year old forest, dominated by Douglas-fir, western hemlock and western red cedar in the CWH zone. They reported a SOC content of $15.9 \mathrm{~kg} \cdot \mathrm{Cm}^{-2}$ compared to $11.0 \mathrm{~kg} \cdot \mathrm{Cm}^{-2}$ to $60 \mathrm{~cm}$ depth for our mixed forest. Despite differences in species composition between the forests, the SOC content of the solum is similar between the study of Grand and Lavkulich (2011) and this study, and corroborates that low magnitude disturbance of old-growth forest might not have a critical long term legacy effect on SOC content compared to high magnitude disturbances, despite changes in species composition.

Similar to our study, Latty et al. (2004) found that old-growth forest soils had higher total C than severely disturbed forest (historically logged and then burned). Their "severely disturbed" forest could be compared to our alder forest. Latty et al. (2004) showed that even low severity disturbances left legacies on ecosystem processes that were detected nearly 100 years later, which does not seem to be the case in this study. Further, Hobley et al. (2015) suggested that the storage of SOC near the surface was driven predominately by climate, while at depth the influence of climate waned and soil factors and disturbance history became more important. That has relevant implications in our study given that SOC stocks of the mineral horizons accounted for one third of the total SOC stocks in the mixed and alder forests and half of that for the coniferous forest.

With respect to soil properties, the coarse nature of the soil and the presence of a thick root network did not allow precise BD field measurements, thus BD has been estimated. Périé and Ouimet (2008) recommended using the organic density approach to estimate $\mathrm{BD}$ from $\mathrm{SOM}$ because it allows $\mathrm{BD}$ to be predicted without significant bias and with a degree of accuracy of $14 \%$. The values for $\mathrm{D}_{\mathrm{bm}}$ and $\mathrm{D}_{\mathrm{bo}}$ were also chosen by Grand and Lavkulich (2011) for Humo-Ferric Podzol evaluations on glacial till on the Sunshine Coast of southwestern British Columbia and are in good agreement with other studies conducted in medium to coarse-textured acid forest soils (Federer et al., 1993). BD values for soil horizons were similar to those reported by Shaw et al. (2005) for the FH layer of an Orthic Humo-Ferric Podzol but lower for the mineral horizons $\mathrm{Ah}, \mathrm{Bf} 1$ and $\mathrm{Bf}_{2}$. The range in values was comparable to those reported by Grand and Lavkulich (2011) for the same soil subgroup. Lower average soil BD values for the mixed and coniferous forests indicated higher SOM concentrations, and hence higher degree of soil porosity, as well as lower degree of soil compaction. Organic C storage was calculated based on SOC concentration, estimated BD, the thickness of horizons and the fine earth fraction. The uncertainty associated with estimation of BD values, including the prediction error of the pedotranfer functions themselves, plus the uncertainty of the determination of SOC concentration, is discussed by Schrumpf et al. (2011). This discussion was considered in assessing the variability and reliability of the estimates associated with SOC concentration and depth for the fine earth mineral soil 
and the variability associated with the determination of $\mathrm{D}_{\mathrm{bm}}, \mathrm{D}_{\mathrm{bo}}$ and SOM for the organic layer, thus the results are comparative. Schrumpf et al. (2011) demonstrated that this variability was the result of the variability of SOC concentration (due to laboratory errors and to the high SOC spatial variability) and the coarse fragment ( $>2 \mathrm{~mm}$ ) content. In this study coarse fragments SOC content was not taken into account. Homann et al. (2005) found that, on average, the coarse fragment SOC content contained less than $1 \mathrm{~kg} \cdot \mathrm{m}^{-2}(0-20 \mathrm{~cm})$ in old-growth forests of Sitka spruce [Picea sitchensis (Bong.) Carr] and western hemlock of western Washington and Oregon.

\subsection{Stability of SOC}

Doetterl, et al. (2015) suggested that the interaction between climate and geochemical (pedogenic) factors controlled SOC storage and turnover. In our study, SOC was found to be associated with the silt and clay fraction, similar to the findings of Kalbitz and Kaiser (2007). The coarse textured soil of the study area contained few aggregates, thus sorption of SOC to coated mineral surfaces may play an important role in SOC stabilization and sequestration (Kaiser et al., 2002). Further, for podzolic soils, Kaiser et al. (2002) stated that amorphous $\mathrm{Al}$ and Fe oxides are the most important substrates for the formation of organo-mineral associations and thus for the SOC stabilization. Likewise, interactions between SOC and amorphous $\mathrm{Fe}$ and $\mathrm{Al}$ oxides have been postulated to be the main mechanism of SOC stabilization in other acid soils (Rumpel \& KögelKnabner, 2011). Yet the soils of the mixed and coniferous forests were characterized by higher $\mathrm{Al}$ concentrations in the mineral horizons and higher concentrations of stable SOC. Although we compared different species compositions, our results agree with Latty et al. (2004) and Nave et al. (2010), who compared different forest ecosystems with the same overstory species composition and suggested that mature forests with an history of minimal disturbance have the potential to sequester a larger quantity of recalcitrant SOC than do seral forests. We found that there was more recalcitrant SOC per gram of soil in the surface Ah horizon than in the subsoil horizons of the alder forest (result not shown). This may indicate that SOC compounds in the deep soil horizons of our forests are not highly decomposed. However, according to Rumpel and Kögel-Knabner (2011), the addition of labile SOC in subsoil horizons could lead to destabilization of SOC with a high residence time. In our study, disturbances (depending on the magnitude) may have caused the enrichment of deep horizons with labile SOC due to mixing and erosion, especially under the humid and podzolizing conditions of the study area. Our study suggests that the higher base status, higher finer particle size fraction and higher $\mathrm{pH}$ under the alder forest in comparison to the mixed or coniferous forests could have resulted in a rapid turn-over of SOC. Furthermore, soils that have higher base status are known to have greater rates of humification (Edmonds, 1980).

The disturbance of "intermediate" magnitude that led to the regeneration of the coniferous forest contributed to changes in the chemical properties of the $\mathrm{Bf}_{1}$ horizon. For example the wider $\mathrm{C}: \mathrm{N}$ ratio of the $\mathrm{Bf}_{1}$ horizon of the coniferous forest compared with the mixed and alder forests and the higher concentrations of SOC were probably due to a higher decomposition rate of SOM. The difference in litter quality of Douglas-fir is 
known to change the nature of the main source of SOC in the subsoil (Edmonds, 1980) and thus could help explain the observed difference in SOC concentrations among forest sites. In addition, organic acids (i.e. fulvic acid) resulting from Douglas-fir litter decomposition might become mobile and thus contribute to the accumulation of SOC in the lower Bf $\mathrm{f}_{1}$ horizon (Kalbitz \& Kaiser, 2007). Consistent with Latty et al. (2004), our results suggest that changes in species composition following disturbance events, may lead to changes in litter quality that can further impact SOC storage. Interpreting the values of C:N ratio in the light of past disturbances is complex in this study because of the change in species composition and large biological differences between red alder and conifers. Indeed, red alder is able to obtain $\mathrm{N}$ from a symbiotic relationship with Frankia, a $\mathrm{N}_{2}$-fixing actinomycete (Bollen \& Lu, 1968). This species produces leaf litter with a higher $\mathrm{N}$ content compared to conifer species. Thus soil beneath alder should be generally higher in $\mathrm{NO}_{3}^{-}$and nitrifying capacity (Bollen \& Lu, 1968). The higher amount of silt and clay in the alder forest suggests that there might be a greater influence of the Newton stony clay (the original parent material) reflected by possible erosion following the original disturbances. The finer soil of the parent material could have been incorporated into the present soil of this forest as a result of past disturbances.

\section{Conclusions}

In this study, we compare SOC stocks and stability of three second-growth forests in PSRP of British Columbia. These three forests result from disturbance events of different magnitudes that occurred in old-growth at the beginning of the 20th century. Since then, forests in the park were left to grow back naturally. We focus our study on a single geographical area with a documented history, and use this framework for a comparative study. Our results suggest that:

i) The forest that results from selective logging and comparatively low severity fire (low magnitude disturbances) store more $\mathrm{SOC}$ to $30 \mathrm{~cm}$ depth than forests resulting from disturbances of higher magnitude (coniferous and alder forests).

ii) Stable SOC concentration is lowest in the alder forest that regenerated from disturbances of the highest magnitude. The soil of this forest has the narrowest C:N ratio, which reflects the nature of the litter and contains lower extractable $\mathrm{Al}$ concentration, which plays an important role in SOC stabilization in coastal temperate forests.

In our study area, legacies of disturbances depend on the disturbance magnitudes. High magnitude disturbances that were followed by the regeneration of early successional tree species, led to an increase in SOC turnover. In this case, negative soil-plant interactions (as an example, through changes in litter quality) may further reduce SOC storage, although this aspect was beyond the scope of our study. Our study gave an insight into the role of disturbance history in reducing SOC storage capacity of recovering coastal temperate forests of BC.

\section{Acknowledgements}

We thank Markus Merkens, natural resource management of PSRP. We thank Gladys Oka for her help in designing the project, Martin Hilmer, Hans Schreier and Darrell 
Hoffman for technical assistance, Maureen Soon, Alice Chang for soil laboratory analysis as well as Gary Bradfield and Christine Fant for data management advice. This research was funded by the graduate training program TerreWEB (NSERC/CRSNG CREATE grant) at the University of British Columbia and the regional council of Bourgogne (France).

\section{References}

Baldock, J. A., \& Skjemstad, J. O. (2000). Role of the Soil Matrix and Minerals in Protecting Natural Organic Materials against Biological Attack. Organic Geochemistry, 31, 697-710. http://dx.doi.org/10.1016/S0146-6380(00)00049-8

Bate, T. E. (1993). Soil Handling and Preparation. In M. R. Carter (Ed.), Soil Sampling and Methods of Analysis (pp. 19-24). Boca Raton, FL: Lewis Publisher.

Bhatti, J. S., Apps, M. J., \& Tarnocai, C. (2002). Estimates of Soil Organic Carbon Stocks in Central Canada using Three Different Approaches. Canadian Journal of Forest Research, 32, 805812. http://dx.doi.org/10.1139/x01-122

Black, T. A., Jassal, R. S., \& Fredeen, A. L. (2008). Carbon Sequestration in British Columbia's Forests and Management Options (17 p). Victoria, BC: Forestry, Pacific Institute for Climate Solutions.

Bollen, W. B., \& Lu, K. C. (1968). Nitrogen Transformations in Soil Beneath Red Alder and Conifers. In J. M. Trappe, J. F. Franklin, R. F. Tarrant, \& G. M. Hansen (Eds.), Biology of Alder (pp. 141-148). Portland, OR: Pacific Northwest Forest and Range Experiment Station Forest Service, U.S. Department of Agriculture.

British Columbia Ministry of Forests and Range and British Columbia Ministry of Environment (2010). Field Manual for Describing Terrestrial Ecosystems (2nd ed., 266 p). Land Manag. Handbook (25), Victoria, BC: Research Branch B.C. Ministry of Forests and Range.

Carpenter, D. N., Bockheim, J. G., \& Reich, P. F. (2014). Soils of Temperate Rainforests of the North American Pacific Coast. Geoderma, 230-231, 250-264.

http://dx.doi.org/10.1016/j.geoderma.2014.04.023

Carrillo, Y., Ball, B. A., Strickland, M. S., \& Bradford, M. A. (2012). Legacies of Plant Litter on Carbon and Nitrogen Dynamics and the Role of the Soil Community. Pedobiologia, 55, 185192. http://dx.doi.org/10.1016/j.pedobi.2012.02.002

Dahlgren, R. A. (1994). Quantification of Allophane and Imogolite. In: J. E. Amonette, \& L. W. Zelazny (Eds.), Quantitative Methods in Soil Mineralogy (p. 430). Madison, WI: SSSA Miscellaneous Publication.

Doetterl, S., Stevens, A., Six, J., Merckx, R., Van Oost, K., Pinto, M. C., et al. (2015). Soil Carbon Storage Controlled by Interactions between Geochemistry and Climate. Nature Geoscience, 8 , 780-783. http://dx.doi.org/10.1038/ngeo2516

Edmonds, R. L. (1980). Litter Decomposition and Nutrient Release in Douglas-Fir, Red Alder, Western Hemlock and Pacific Silver Fir Ecosystems in Western Washington. Canadian Journal of Forest Research, 10, 327-337. http://dx.doi.org/10.1139/x80-056

Eusterhues, K.,Rumpel, C., \& Kögel-Knabner, L. (2005). Organo-Mineral Associations in Sandy Acid Forest Soils: Importance of Specific Surface Area, Iron Oxides and Microspores. European Journal of Soil Science, 56, 753-763. http://dx.doi.org/10.1111/j.1365-2389.2005.00710.x

Federer, C. A., Turcotte, D. E., \& Smith, C. T. (1993). The Organic Fraction Bulk Density Relationship and the Expression of Nutrient Content in Forest Soils. Canadian Journal of Forest Research, 23, 1026-1032. http://dx.doi.org/10.1139/x93-131 
Grand, S., \& Lavkulich, L. M. (2011). Depth Distribution and Predictors of Soil Organic Carbon in Podzols of a Forested Watershed in Southwestern Canada. Soil Science, 176, 164-174. http://dx.doi.org/10.1097/SS.0b013e3182128671

Grand, S., \& Lavkulich, L. M. (2012). Effects of Forest Harvest on Soil Carbon and Related Variables in Canadian Spodosols. Soil Science Society of America Journal, 76, 1816-1827.

http://dx.doi.org/10.2136/sssaj2012.0103

Harmon, M. E., Ferrell, W. K., \& Franklin, J. F. (1990). Effects on Carbon Storage of Conversion of Old-Growth Forests to Young Forests. Science, 247, 699-702. http://dx.doi.org/10.1126/science.247.4943.699

Hendershot, W. H., Lalande, H., \& Duquette, M. (1993). Soil Reaction and Exchangeable Acidity, Soil pH in Water, Soil pH in $0.01 \mathrm{C}_{\mathrm{a}} \mathrm{Cl}_{2}$. In M. R. Carter (Ed.), Soil Sampling and Methods of Analysis (pp. 141-144). Canadian Society of Soil Science, Boca Raton, FL: CRC Press LLC.

Hendershot, W. H., \& Duquette, M. (1986). Exchangeable Cation and Effective CEC by the $\mathrm{BaCl}_{2}$ Method. In M. R. Carter (Ed.), Soil Sampling and Methods of Analysis (pp. 168-170). Canadian Society of Soil Science, Boca Raton, FL: CRC Press LLC.

Heuscher, S. A., Brandt, C. C., \& Jardine, P. M. (2005). Using Soil Physical and Chemical Properties to Estimate Bulk Density. Soil Science Society of America Journal, 69, 51-56.

Hobley, E., Wilson, B., Wilke, A., Gray, J., \& Koen, T. (2015). Drivers of Soil Organic Carbon Storage and Vertical Distribution in Eastern Australia. Plant and Soil, 390, 111-127. http://dx.doi.org/10.1007/s11104-015-2380-1

Homann, P. S., Harmon, M., Remillard, S., \& Smithwick, E. A. H. (2005). What the Soil Reveals: Potential Total Ecosystem C Stores of the Pacific Northwest Region, USA. Forest Ecology and Management, 220, 270-283. http://dx.doi.org/10.1016/j.foreco.2005.08.035

Kaiser, K., Eusterhues, K., Rumpel, C., Guggenberger, G., \& Kögel-Knabner, I. (2002). Stabilization of Organic Matter by Soil Minerals-Investigations of Density and Particle-Size Fractions from Two Acid Forest Soils. Journal of Plant Nutrition and Soil Science, 165, 451-459. http://dx.doi.org/10.1002/1522-2624(200208)165:4<451::AID-JPLN451>3.0.CO;2-B

Kalbitz, K., \& Kaiser, K. (2007). Contribution of Dissolved Organic Matter to Carbon Storage in Forest Mineral Soils. Journal of Plant Nutrition and Soil Science, 170, 52-60.

Kalra, Y. P., \& Maynard, D. G. (1991). Methods Manual for Forest Soil and Plant Analysis (125 p). Edmonton: Forestry Canada, Northwest region, Northern Forestry Center. Information Report NOR-X-319.

Keith, H., Mackey, B. G., \& Lindenmayer, D. B. (2009). Re-Evaluation of Forest Biomass Carbon Stocks and Lessons from the World's Most Carbon-Dense Forests. Proceedings of the National Academy of Sciences of the United States of America, 106, 11635-11640. http://dx.doi.org/10.1073/pnas.0901970106

Kettler, T. A., Doran, J. W., \& Gilbert, T. L. (2001). Simplified Method for Soil Particle-Size Determination to Accompany Soil-Quality Analyses. Soil Science Society of America Journal, 65, 849-852. http://dx.doi.org/10.2136/sssaj2001.653849x

Klassen, A., \& Tevershams, J. (1977). Exploring the UBC Endowment Lands (111 p). Vancouver: J.J. Douglas Ltd.

Laganière, J., Paré, D., Bergeron, Y., Chen, H. T. H., Brassard, B. W., \& Cavard, X. (2013). Stability of Soil Carbon Contents Varies with Forest Composition in the Canadian Boreal Biome. Ecosystems, 16, 852-865. http://dx.doi.org/10.1007/s10021-013-9658-Z

Latty, E. F., Canham, C. D., \& Marks, P. L. (2004). The Effects of Land-Use History on Soil Properties and Nutrient Dynamics in Northern Hardwood Forests of the Adirondack Mountains. Ecosystems, 7, 193-207. http://dx.doi.org/10.1007/s10021-003-0157-5 
Lavkulich, L. M., \& Rowles, C. A. (1971). Effect of Different Land Use Practices on a British Columbia Spodosol. Soil Science, 111, 323-329. http://dx.doi.org/10.1097/00010694-197105000-00010

Lützow, M. V., Kögel-Knabner, I., Ekschmitt, K., Matzner, E., Guggenberger, G., Marschner, B., \& Flessa, H. (2006). Stabilization of Organic Matter in Temperate Soils: Mechanisms and their Relevance under Different Conditions-A Review. European Journal of Soil Science, 57, 426445. http://dx.doi.org/10.1111/j.1365-2389.2006.00809.x

Matsuzaki, E., Sanborn, P., Fredeen, A. L., Shaw, C. H., \& Hawkins, C. (2013). Carbon Stocks in Managed and Unmanaged Old-Growth Western Red Cedar and Western Hemlock Stands of Canada's Inland Temperate Rainforests. Forest Ecology and Management, 297, 108-119. http://dx.doi.org/10.1016/j.foreco.2012.11.042

Maynard, D., \& Curran, M. (1993). Bulk Density Measurement in Forest Soils. In M. R. Carter (Ed.), Soil Sampling and Methods of Analysis (pp. 863-869). Canadian Society of Soil Science, Boca Raton, FL: CRC Press LLC.

McKeague, J. A., \& Day, J. H. (1966). Dithionite and Oxalate Extractable Fe and Al as Aids in Differentiating Various Classes of Soils. Canadian Journal of Soil Science, 46, 13-22.

http://dx.doi.org/10.4141/cjss66-003

Meidinger, D., \& Pojar, J. (Eds.) (1991). Ecosystems of British Columbia (342 p). Special Report Series 6, Victoria, BC: B.C. Ministry of Forests and Range Research Branch.

Nave, L. E., Vance, E. D., Swanston, C. W., \& Curtis, P. S. (2010). Harvest Impacts on Soil Carbon Storage in Temperate Forests. Forest Ecology and Management, 259, 857-866. http://dx.doi.org/10.1016/j.foreco.2009.12.009

Périé, C., \& Ouimet, R. (2008). Organic Carbon, Organic Matter and Bulk Density Relationships in Boreal Forest Soils. Canadian Journal of Soil Science, 88, 315-325.

http://dx.doi.org/10.4141/CJSS06008

Rumpel, C., \& Kögel-Knabner, I. (2011). Deep Soil Organic Matter-A Key but Poorly Understood Component of Terrestrial C Cycle. Plant and Soil, 338, 143-158. http://dx.doi.org/10.1007/s11104-010-0391-5

Schleuß, P.-H., Heitkamp, F., Leuschner, C., Fender, A.-N., \& Jungkunst, H. F. (2014). Higher Subsoil Carbon Storage in Species-Rich than Species-Poor Temperate Forests. Environmental Research Letters, 9, 014007. http://dx.doi.org/10.1088/1748-9326/9/1/014007

Schmidt, M. W. I., Torn, M. S., Abiven, S., Dittmar, T., Guggenberger, G., Janssens, I. A., et al. (2011). Persistence of Soil Organic Matter as an Ecosystem Property. Nature, 478, 49-56. http://dx.doi.org/10.1038/nature10386

Schrumpf, M., Schulze, E. D., Kaiser, K., \& Schumacher, J. (2011). How Accurately Can Soil Organic Carbon Contents and Contents Changes Be Quantified by Soil Inventories? Biogeosciences, 8, 1193-1212. http://dx.doi.org/10.5194/bgd-8-723-2011

Shaw, C., Bhatti, J., \& Sabourin, K. (2005). An Ecosystem Carbon Database for Canadian Forests (113 p). Edmonton: Natural Resources Canada. Canadian Forest service, Northern Forestry Center. Information Report NOR-X-403.

Soil Classification Working Group (1998). The Canadian System of Soil Classification (3rd ed., 187 p). Ottawa: Agriculture and Agri-Food Canada Publication 1646 (Revised).

Sparks, D. L., Page, A. L., Helmke, P. A., \& Loeppert, R. H. (1996). Methods of Soil Analysis Part 3-Chemical Methods. Soil Science Society of America Book Series 5.3. Madison, WI: Soil Science Society of America, American Society of Agronomy.

Thompson, G. A. (1985). Vegetation Classification of the Endowment Lands. Technical Paper (4), Burnaby: Greater Vancouver Regional District Parks Department. 
Wang, T., Hamann, A., Spittlehouse, D. L., \& Murdock, T. Q. (2012). Climate WNA, High Resolution Spatial Climate Data for Western North America. Journal of Applied Meteorology and Climatology, 51, 16-29. http://dx.doi.org/10.1175/JAMC-D-11-043.1

Waring, R. H., \& Franklin, J. F. (1979). Evergreen Coniferous Forests of the Pacific Northwest. Science, 204, 1380-1386. http://dx.doi.org/10.1126/science.204.4400.1380

Zimmerman, M., Leifeld, J., Abiven, S., Schmidt, M. W. I., \& Fuhrer, J. (2007). Sodium Hypochlorite Separates an Older Soil Organic Matter Fraction than Acid Hydrolysis. Geoderma, 139, 171-179. http://dx.doi.org/10.1016/j.geoderma.2007.01.014

Submit or recommend next manuscript to SCIRP and we will provide best service for you:

Accepting pre-submission inquiries through Email, Facebook, LinkedIn, Twitter, etc.

A wide selection of journals (inclusive of 9 subjects, more than 200 journals)

Providing 24-hour high-quality service

User-friendly online submission system

Fair and swift peer-review system

Efficient typesetting and proofreading procedure

Display of the result of downloads and visits, as well as the number of cited articles

Maximum dissemination of your research work

Submit your manuscript at: http://papersubmission.scirp.org/ 